\title{
People-Centred Approaches to Peace: At Cross Roads Between Geopolitics, Norms, and Practice
}

\author{
Youssef Mabmoud
}

"We the Peoples" and the Act of Creation ${ }^{1}$

On the eve of the 2015 world leaders' summit that would unanimously adopt the 2030 Sustainable Development Agenda, "We the peoples," the emblematic first three words of the UN Charter, were on full display during an art exhibit at the United Nations. In 1953, the American painter, Norman Rockwell, had been so hopeful about the creation of the United Nations that he sketched a drawing entitled the United Nations after the newly formed organisation (Husain 2015). The sketch features in the foreground the representatives of the Governments of the United States, the United Kingdom, and the now-defunct Soviet Union. In the background, people of all ages and from different cultural and ethnic backgrounds looked over the shoulders of these representatives,

\footnotetext{
${ }^{1}$ See Schlesinger (2004).
}

Y. Mahmoud ( $\square)$

International Peace Institute (IPI), Vienna, Austria

(C) The Author(s) 2019

C. de Coning and M. Peter (eds.), United Nations

Peace Operations in a Changing Global Order, https://doi.org/10.1007/978-3-319-99106-1_5 
with anxious but hopeful eyes. Rockwell never finished this sketch. Instead, in 1961, he drew from it to complete his now famous painting "the Golden Rule" (Norman Rockwell Museum 2014), currently on permanent display at the UN headquarters, featuring the same figures of the people in the background but without the Government representatives in the front. A likely interpretation is that, after his original drawing eight years earlier, he had decided to de-emphasise governments (Reimers 2015): By giving "We the Peoples" centre stage, he wanted to convey the message that when people in their immense diversity and collective wisdom stand together in dignity and mutual respect, they can achieve the common goals enshrined in the Charter.

No one could have predicted that Rockwell's decision to remove government representative from the "Golden Rule" rendition of the "United Nations" would be a harbinger of the complex and, at times, tense state-society relations we are witnessing today in many parts of the world.

Many of the 50 founding states that had signed the Charter in June 1945 were undemocratic. Yet no one contested their right to speak for the people, who were admittedly exhausted from the ravages of World War II. Things are different today. While most governments are democratically elected, their remit to speak for "we the peoples" is regularly challenged (van Tongeren 2005). Aided by the democratisation of information, education, and the forces of globalisation, ordinary citizens and networks of interconnected people have become aware of the performance of their governments and thus do not shy away from vociferously making known their views about the quality of the services they expect from these governments. As attested by the wave of protest movements that swept over parts of Africa, the Middle East and several countries in Latin America, citizens are no longer content with the proposition that their right to change non-performing governments can only be exercised during election periods.

Global challenges such as development deficits, health pandemics, drug trafficking, food security, water, climate change, poverty reduction, criminal networks, and terrorism are no longer transnational problems for governments alone to worry about, echoing the conclusions of the Panel of Eminent Persons on United Nations-Civil Society Relations (UN 2004). This shift was in full display during the UN's 70th anniversary celebration where foreign policy discourse was not so much about augmenting the power of the state as about serving the people (Center for Strategic and International Studies 2015). 


\section{"We the Peoples" in Development and Peace and Security}

People-centred approaches are not a novelty for the UN system. In the early nineties, the UN Development Programme (UNDP) struck a balance between state-centric and people-centred approaches, most notably in its Human Development Report (HDR). Now its flagship publication, the HDR, was first launched in 1990 with the Pakistani economist Mahbub ul Haq as a key instigator. The aspiration was to put people centre stage in debates on development, which goal was to provide people with opportunities and choices (United Nations Development Programme 2017). "People are the real wealth of a nation," Haq wrote in the opening lines of the first HDR (United Nations Development Programme 1990). "The basic objective of development is to create an enabling environment for people to enjoy long, healthy and creative lives." It is no surprise, therefore, that the UNDP's core mission is to empower people and build the resilience of nations.

The unanimous adoption in 2015 by the UN General Assembly of the 2030 Agenda for Sustainable Development and the Paris Agreement on Climate Change have been hailed as much as state achievements as a "peoples" achievement. The first was touted as a global social contract between the peoples' world and their states, and the second a trilateral compact, a covenant between states, peoples, and the planet. Both constitute a remarkable proclamation of hope at a time when the world is torn by much strife and violent conflict. The intense engagement and mobilisation of grass root movements throughout the consultation process and the relentless pressure they exercised on world leaders account for the sense of collective ownership by all stakeholders of these two universal agendas (Leiva-Roesch et al. 2014). As the Panel of Eminent Persons on United Nations-Civil Society Relations concluded (UN 2004 , p. 3), "constructively engaging with civil society is a necessity for the United Nations, not an option."

\section{“We the Peoples" in Peace and Security}

In the area of peace and security, integrating people- or community-centred approaches to manage conflict has been a slow process met with occasional pushback. Despite the pervasive awareness that contemporary conflicts are largely occurring within states and tend to be driven from below-often by non-state actors and citizens with 
unanswered grievances-the UN Security Council, designed to prevent and arbitrate interstate conflicts, has been struggling to adapt its statecentric approaches to these new realities. Its mandate design is still dominated by the assumption that fixing imperfect or weak states, securing their juridical legitimacy through elections, and extending their remit throughout a particular territory would yield peace dividends for citizens and communities. This dominant paradigm equates state-building with peacebuilding, impervious to the empirical evidence indicating otherwise (Call 2012). This point was not lost on the g7+ Group of countries, composed of mostly fragile and conflict affected states, when they agreed in 2011 together with their international development partners on the five peacebuilding and state building goals that should guide their collective action out of fragility (G7plus 2017). Thus it comes as no surprise that the first goal gave primacy to legitimate politics over state building. Their firm view was that no state authority is viable without inclusive, participatory governance and equitable delivery of basic services to the people.

\section{HipPO and the Challenges of People-Centred}

\section{APPROACHES}

It is against this background that the High Level Independent Panel on Peace Operations (HIPPO) set out to fulfil the mandate entrusted to it by the UN Secretary-Secretary in October 2014 (UN 2014). The High-Level Panel (henceforth the Panel) devoted considerable time in developing a shared and practical understanding of what was meant by people-centred approaches to peace operations before advocating these approaches as one of the essential shifts (UN 2015a, pp. viii and 16) that had to be embraced in the future in the design and delivery of UN peace operations. As a panel, we argued for a "renewed resolve on the part of United Nations peace operations personnel to engage with, serve and protect the people they have been mandated to assist." The Panel, not unlike the Advisory Group of Experts on the Review of the Peacebuilding Architecture and the High Level Advisory Group on the implementation of Security Council Resolution 1325, considered sustaining peace (UN $2015 a$, p. 34) as the ultimate objective of UN post conflict engagements in which inclusive politics and people in their plurality, particularly women and youth, played a central role. 
Panel members were keenly aware that reaching out to people and engaging with local communities and ordinary citizens are common practices in many peace operations, notwithstanding the Council's halfhearted acceptance of the concept as outlined above. These field practices ranged from local perception surveys on mission performance, to communication and sensitisation outreach programs through UN radios.

However, the Panel felt that these practices tended to take the form of discrete activities, without sufficient strategic focus on their connections to self-sustainable peace. Whether stemming from Security Council mandates or conceived by field missions, community engagement activities appeared as mission-centric (e.g. winning hearts and minds of local populations) or as appendices to various state-centric goals that were judged to be far more critical to stability, such as sustaining a fragile peace agreement, holding elections, or restoring and extending state authority. The latter activity tended to be carried out in a way that emphasised control by the centre rather than empowerment of the peripheries and their forms of self-government, especially in areas that had escaped government control in the past and where invariably the state suffers from a trust deficit. The Panel was also aware that in peacekeeping missions, operating in hostile environments where much of the military assets are mobilised to prevent or counter asymmetric threats, the space for meaningful community outreach tends to be limited or compromised, at times even securitised.

In pointing out the above shortcomings and operational constraints, HIPPO members were equally aware that people-centred approaches, are not without dilemmas, challenges, or risks, particularly in complex conflict environments and notwithstanding normative advances, policy prescriptions, good practices, and guidance notes (UN 2015a, p. 66).

The central challenge for a state-centric instrument such as peacekeeping is to what extent it should have its own mechanisms for engaging and consulting directly with "we the peoples" without making government officials feel that their unique prerogative, as elected representatives to engage with their own people, has been usurped (van Tongeren 2005) and thus would insist on being involved. The flip-side of this dilemma is how to partner with the government in this endeavour without the latter capturing UN devised people-focused processes for narrow political gains, including using them to shore up any perceived lack of performance legitimacy. 
Another challenge is that it is not easy to identify, outside elite circles, civil society representatives who genuinely speak on behalf of local people. Therefore, questions of who and when and how to engage become central. Reaching out to communities associated with insurgent movements or terrorist groups that UN peace operations are expected to keep at arms-length, or even neutralise, could put UN personnel at risk (de Coning et al. 2015).

An additional challenge is the lack of capacity for rigorous analysis of local realities. This would require among other things a shift from focusing only on the drivers of conflict and fragility to identifying the communities' endogenous capacities for peace and resilience. These usually include local norms, physical structures, traditional governance institutions, and networks through which information is collected and disseminated and mutual assistance is provided (UN 2015a, p. 35). It is these informal coping mechanisms that people turn to in times of national or local stresses, whether they are man-made or nature-induced (Interpeace 2016). And it is these very capacities that peace operations need to strengthen so as to help lay the foundation for less reversible and, hopefully, self-sustaining peace. In the absence of such analyses, missions tend to resort to ad-hoc programmatic interventions that are not well thought-out or that unwittingly may do more harm than good.

Another factor that has been found to contribute to unintended consequences is the tendency of the UN to value thematic expertise (DDR, SSR, electoral processes) over local knowledge. This legitimises the deployment of people to missions who do not speak any of the local languages, nor are fully versed or interested in the custom, norms, and behaviours of the host country. They tend to look at complex local problems through the lens of their expertise with supply-driven solution at the ready.

A further challenge that was brought to the attention of Panel members is that because of concerns for staff security and safety, particularly in hostile environments, there was and still is a tendency to gather information on local peace and conflict dynamics from expatriates living in fortified compounds (Autesserre 2015). Attempts to address this deficit by relying on information provided by national Community Liaison Officers or Assistants in the employment of the mission have sometimes backfired or endangered their lives. This is particularly the case when local communities that are hostile to the mission or the government start suspecting these local employees (particularly those attached to UN military 
compounds) of using their privileged access to their communities to spy on them. The increasingly explicit emphasis on enhanced human intelligence capabilities as a force multiplier or for security and effective mandate implementation has fuelled these suspicions.

\section{HiPPO Specific Recommendations, UN SG's Follow-ON Report, and Member States’ Reactions}

In order to overcome the above dilemmas and challenges, the Panel called for a number of shifts in mindset and operational practices and made several specific recommendations. The most salient of these are discussed below.

For the Panel, countries emerging from conflict "are not blank pages and their people are not 'projects" (UN 2015a, p. 34). As outlined above, these people possess knowledge, expertise, and resilient mechanisms that help withstand the stresses of conflict. Therefore, the Panel called for a shift from merely consulting with these people in order to validate pre-conceived ideas and solutions, to actively engaging with them so as to hear their perspectives and monitor and respond to how they experience the impact of the peace operation and ensure that the mission does no harm (UN 2015a, p. 24). In this connection, the Panel stressed the need to allocate the appropriate resources to, on a regular basis, conduct "independent surveys of local perceptions of the mission and progress towards mission objectives" (UN 2015a, p. 39). They also called on missions "to develop strategies for community engagement at various stages of the mission cycle-from assessment, analysis, planning, implementation, review and evaluation-and make increased and judicious use of national staff in designing and implementing these strategies" (UN 2015a, p. 66).

With respect to analysis, the Panel recommends that missions should focus inter-alia on identifying the local structures for managing and mitigating conflict, resource flows, and revenue or illicit power networks (UN 2015a, p. 46). Missions should also engage in differentiated and gender sensitive conflict analysis to better understand the specific experience, rights, needs, perspectives, and roles of women and girls in conflict situations (UN 2015a, p. 67). This would in turn "inform strategies for their protection and participation," and enable missions to draw on the expertise of local women leaders, and women's organisations (UN 2015a, p. 67). 
With respect to community dynamics in zones of conflict, the Panel recommended that peace operations "should maintain the closest possible interaction with the communities and support national initiatives regarding rural and local development. Missions should lend their assistance to the resolution of local conflicts, and support community efforts to move toward reconciliation" (UN 2015a, p. 39).

In his follow-up report "The Future of UN Peace Operations" (UN 2015b), Secretary-General Ban Ki-Moon endorsed the strategic shift for a people-centred approach to peace operations and highlighted the specific, practical initiatives the Secretariat was already engaged in to implement many of the recommendations outlined in the Panel's report under this rubric. These include public opinion surveys undertaken by many missions to regularly assess progress and evolving community priorities, to recruiting national staff and community liaison officers to help the missions foster public support for their mandates (UN 2015b, p. 27), to guidance notes on how to understand local perceptions.

In its 2016 substantive session report (UN 2016a), the Special Committee on Peacekeeping Operations (UN 2016a, p. 34) expressed its support for more people-centred approaches in peacekeeping, "including through local level analysis that draws on more strategic engagement with communities and an understanding of local perceptions and priorities" (UN 2016a, para. 131). It also noted that "effective mission-wide communication strategies can enable peacekeeping operations to build trust with local communities, manage expectations... and improve awareness of the work and contributions of UN personnel in complex and challenging environments" (UN 2016a, para. 133).

The Security Council has held several thematic debates on the contents and recommendations of the HIPPO report and the SG follow-on report, the most important of which took place on 20 November 2015 (UN 2015c). The ensuing Presidential Statement (UN 2015d), issued five days after intense negotiations among Council members, was rather bland and made no reference to people-centred approaches in peacekeeping. The Resolution (UN 2016b) the Council unanimously adopted on 27 April 2016 jointly with the GA on sustaining peace was, however, hailed a significant conceptual and policy shift on the part of the Council (Mahmoud 2016). It argues that sustaining peace be "broadly understood as a goal and a process to build a common vision of a society ensuring that the needs of all the segments of the population are taken into account." The joint resolution also emphasises that sustaining 
peace is "a shared task and responsibility that needs to be fulfilled by the government and all other national stakeholders." Throughout the resolution, civil society organisations, women's groups, youth organisations, and, where relevant, the private sectors were often mentioned as key strategic and operational partners in moving the sustaining peace agenda forward.

On 10-11 May 2016, the President of the General Assembly convened a High Level thematic debate on the synergies between the three peace and security global policy reviews mentioned in the first part of this paper and issued a Chair summary containing a series of conclusions and observations. In this summary, it is stated that "the two-day debate made it clear that civilians are the main stakeholders of peace operations with the most to gain from their successes and the most to lose from their failures. Communities should be front and centre in decision-making. Placing people at the centre means also that peace operations are accountable to the people they are meant to serve" (UN 2016c).

Notwithstanding the above conceptual convergence and policy consensus on the importance for people-centred approaches to peace and security and on its constituent elements such as inclusive ownership, the Council in its legislative work continues to shy away from using the exact "people-oriented" phrase, preferring instead to the generic terms "civil society, including women and youth." Where it appears under various guises, it tends to be confined to the preamble part of resolutions rather than in the operational one which has more binding power, with the exception of gender as a cross-cutting theme. A happy exception is the Security Council Resolution 2301 of 26 July 2016 renewing the peacekeeping operation in the Central African Republic (UN 2016d) in which local people's participation and consultations were welcomed. On the contrary, in the one extending the mandate of the peace mission in Mali (MINUSMA) (UN 2016e), people-centred approaches or variations of the phrase are nowhere to be found.

\section{What Would a People-Centred Approach Look like on THE GROUND?}

The purpose of the following paragraphs is to articulate, in light of what was outlined above, how best HIPPO recommendations and the emerging policy consensus on people-centred approaches can be best implemented on the ground. In doing so, the author draws on 
personal field experience, including a recent visit to the UN mission in Mali (MINUSMA), on current best practices by seasoned practitioners, guidance notes for community engagement and insights garnered from scholarly research conducted by de Coning et al. (2015) and Karlsrud (2015) among others. Outlined below are some strategic and programmatic considerations, as well leadership skills and attitudinal shifts which, if heeded, may help achieve this objective, bearing in mind they may need adaptation depending on a mission's political and operational environment.

A starting point for creating a propitious environment for peoplecentred approaches in peace operations is to secure the explicit acceptance and adherence of national authorities to the strategic importance of the policy of inclusive ownership that creates space for all national stakeholders to contribute to self-sustainable peace. This adherence could be a part of the development of a shared understanding of the specific mandate authorised by the Security Council for UN engagement in a particular country, both at the incipient and renewal stages. Where feasible, such a broad understanding of the principles of inclusivity and some of its practical modalities should be part of any agreement that may be drawn between the UN peace mission or the Security Council and the government regarding the practical modalities of implementing the mission's mandate. This contract would provide a measure of transparency in the mission's activities and avoid any misunderstanding with respect to the government's sense of ownership and legitimacy, however tenuous the latter may be. More importantly, it will foster trust and strengthen the initial consent given by host country for the deployment of the mission.

Secondly, and as the High-Level Panel recommended, one should develop a strategy for community engagement at various stages of the mission cycle, that is not only guided by the overall strategic objective of sustaining peace and the principle of doing no harm but also contains elements that address and mitigate some of the dilemmas, challenges, and risks outlined above. To be viable, such a strategy should contain the following:

1. A participatory context analysis that takes peace, and not conflict, as a principal referent that seeks to identify not only the factors that drive and sustain communal violence and the related dynamics, but also the resilience capacities touched upon earlier that communities resort to in times of stress, including local dispute management and reconciliation mechanisms and processes. The analysis, if properly 
designed and conducted, could serve as a barometer for assessing the quality of state-society relations in a particular region or community and thus help guide the implementation of the state-centric provisions of the mission mandate in a context-sensitive manner. In addition, the analysis should include an assessment of risks that community engagement may unwittingly engender. Programmatic interventions, however well designed and intentioned, can be captured by governing elites, create new structures, challenge existing power relations and vested interest, and may even reinforce exclusionary practices. Such an assessment should also evaluate, as the Panel recommended, the impact on the mission mandate and staff security, particularly when local outreach involves engaging with communities targeted by aggressors or judged to be sympathisers of groups that are deemed spoilers or extremists. In other words, inclusivity, noble as it may be, is neither necessarily politically neutral nor always peace-friendly and may therefore cause harm to the mission or the people it is meant to serve.

2. Programmatic interventions devised on the basis of this analysis, including economic recovery and quick impact projects, should build on what people know and where they are, and must contain a self-sustainability clause at the design stage, to enhance ownership and prevent a dependency syndrome. Integrating these interventions within the overall UN Country Team-led reconstruction and development priorities may help achieve this self-sustainability objective, particularly if it is coordinated with other development actors. In this connection, people-centric approaches should be a UN system-wide endeavour. They should also be compatible with and reinforce other mandated mission priorities, such as the restoration and extension of state authority and other state-centric activities. They should serve as a means for enhancing the outreach capacity and legitimacy of the government vis-a-vis its people, and ideally contribute to better state-society relations, particularly in marginalised communities (de Coning et al. 2015). The MINUSMA stabilisation and recovery program has integrated some of the above programmatic considerations and safeguards in its design and implementation modalities, despite the high-risk security environment in which the mission has been deployed.

3. A communication strategy both within and outside the mission is critical. The strategy should be informed by listening sessions and 
regular perception surveys of people who are at the receiving end of mission activities, as recommended by HIPPO and the UN Secretary General.

4. Another critical component of the strategy is a benchmarking component for monitoring and evaluating the effectiveness of community engagement activities and their impact on mission effectiveness.

5. Peace and conflict are gendered, both at the national and the grass roots levels. It is therefore imperative that a gender lens be systematically applied in the design and implementation of the above steps.

Thirdly, to implement a people-centred approach, one should establish, at mission Headquarters and in regional field offices, standing civil society advisory groups. These would include religious, academic leaders, women, and youth representatives, judged to be credible voices for their respective communities. Such groups, as de Coning and colleagues proposed, can provide inputs and/or feedback on the peace and conflict analysis outlined above, "contribute to the mission's self-evaluation of its programmes and initiatives ... [and] enable [it] to stop and re-direct those actions that have harmful effects..." (de Coning et al. 2015, p. 6). "Involving the community," de Coning, Karlsrud, and Troost (Ibid.) add, "not only ensures that the mission's work is relevant to the society it serves, but can also help the peace operation to become a learning organization...". The analysis, as outlined above, if conducted properly, should help overcome the inclusivity and representativeness challenges inherent in the selection of the members of these advisory groups.

The above three prescriptions are not novel and certainly not exhaustive. But if they have a fighting chance of succeeding, they require leadership and attitudinal shifts.

\section{Leadership Shifts}

With respect to leadership, senior mission leaders should invest time and energy early on in their tenure to encourage the government and other national stakeholders to develop a medium to long-term vision of what sustaining peace and development would look like for the country, including some indications on the part to be played by local communities in crafting and achieving that vision. It is not uncommon for 
post conflict countries to devise such a vision. Liberia's and East Timor's 2020 vision are but two examples. Mission leaders should also be seen as engaging meaningfully and on a regular basis with these people-oriented processes both at the strategic and programmatic levels. People-centred activities must be treated as a UN system-wide priority. These activities should not be seen as ancillary, or ad-hoc technical exercises best left to less senior staff, usually under pressure to spend post-haste the funds allocated to these activities. Senior leaders should hold program manager accountable for the sustainability of the peace dividends they are purported to yield, in addition to the immediate goodwill and well-being effects they may generate. Some senior mission leaders tend to treat Security Council mandates as a ceiling and are therefore not inclined to engage in initiatives that are not contained in that mandate even when realities on the ground dictate otherwise. It is hoped that the emerging international consensus around the concepts of sustaining peace, inclusive ownership, and the primacy of politics will encourage these leaders to do what is right for the people they are deployed to serve, without prejudice to the primary responsibilities of the host government, however weak it may be.

\section{Attitudinal Shifts}

With respect to the attitudinal changes that need to take place, I will mention just two. First, there is a pressing need to forego the illusion that the UN builds national ownership by simply consulting people on the ground. The reality is that such consultations tend to be perfunctory, largely dictated by the pressing need to validate situational analyses and assessment that have been made in a hurry or seek the acquiescence for pre-conceived solutions. Not unlike genuine communication, consultation is a two-way street. And in order for that to happen, UN staff need to suspend the certainty that comes from thematic knowledge and expertise and let go of the comfort that past remedies provide. What the UN should do is to start investing in the business of listening-listening with the intent to understand, and not with the intent to solve, advise, or justify. Listening with intent might even help us understand what the UN is not good at and come to the inescapable realisation that building peace is what the local people do, not what outsiders do. A cursory look at any contemporary Security Council resolution should dispel the notion that the burden of building peace rests on outsiders' shoulders. Almost every 
single operative paragraph of these resolutions starts with the key word "support." This is plainly the case of the most recent resolution extending the UN peacekeeping mission in Mali (MINUSMA) (UNSC 2018). The critical message is that the primary responsibility for building peace rests with national actors.

Second, there is an equally urgent need to forego the prescriptive biases of liberal peace (Richmond and Mac Ginty 2014), including the notion that the solution to state imperfections or failures is state building and institutional building. The common assumption informing the state building enterprise where the focus is on technical expertise, and where the emphasis is on juridical legitimacy through elections rather than on performance legitimacy earned through the equitable provision of basic services to "we the peoples," without exclusion. Extending state authority without some degree of performance legitimacy is hardly the best recipe for sustaining peace which is a relational goal, and an integral part of rebuilding the social contract. It looks at the quality of the relationship between the state and the citizen. Context and gender sensitive as well as people-centred approaches to peace and development can help promote a different understanding of legitimacy and ownership and thus may prove more effective for achieving some measure of sustainable peace. In other words, we need to strike a balance between top-down, externally prescribed peace and popular, locally prescribed peace (Roberts 2010).

\section{Conclusion and Recommendation TO THe Security Council}

The world we live in is clearly no longer ordered by states alone, and the monopoly of violence is escaping the grasp of states. As mentioned above, many of the new and emerging threats to international peace and security such as terrorism, organised crime, and violent extremism tend to be driven from below by non-state actors, some with state aspirations. These threats, in addition to their tragic humanitarian consequences, are perceived to constitute a clear and present danger to states and to the state-based multilateral governance system. This partly explains why the UN Security Council tends to resort to state-centric approaches, often militarised, as default responses to counter these threats. These responses, invariably prescribed under Chapter 7 , tend to populate the mandates of contemporary peacekeeping operations. Many of these mandates are guided by the illusory proposition that the best way to repair 
failing states is to build strong state institutions and extend their remit at all cost, without credible checks and balance mechanisms and a reform agenda to address the governance and leadership deficits at the origin of their failures. I am not suggesting that people-oriented peace approaches within a peacekeeping context constitute magic silver bullets. What I am advocating is that these approaches, if properly designed and carried out, can facilitate the capacity of fragile societies to self-organise (de Coning et al. 2015), help repair frayed social contracts and thus make fragile peace less reversible, while the country embarks on the long-term process of building capable, inclusive, and accountable state institutions.

For reasons outlined in this paper and given the resurgence of unhealthy geopolitics within the Council as well as the visceral mistrust of the Council by a majority of the rest of UN members, I do not expect the Council to have a change of heart and fully embrace a people-centred approach to peace operations. What I am encouraging the Council to do is to muster the residual political will and request, as a standard practice, under Chapter 6, nations that are hosts to a peace operation to develop with the support of the UN system on the ground and the Peacebuilding Commission, a compact for sustaining peace that would articulate the primary responsibilities of the host government, the contributions of civil society, and the supportive role to be played by international partners on the ground. All of which will be assorted with an exit strategy undergirded by performance benchmarks and timelines to ensure accountability and facilitate reporting to the Council upon mandate renewal. This will be a strategic framework, not unlike compacts facilitated by the Peacebuilding Commission for certain situations, and not unlike the type of compact proposed by the Panel (UN 2015a, pp. 38-39). It is through this contract, I hasten to add that all the three foundational pillars of UN engagement will flow in an integrated manner, as advocated by Security Council Resolution 2282 (UN 2016c) on sustaining peace, and that people-centred approaches will find a natural and uncontested home.

In the absence of such a framework for mutual accountability, peace operations, particularly in environments of asymmetric threats, will find themselves pressured to make up for the deficits of imperfect states, captured by the political elites, however well-elected they may be, and be far more concerned with power and the next elections than governance. Some of these governing elites might even use the pretext of fighting terrorism and organised violence to escape scrutiny and resist the implementation of the requisite reforms for effective governance 
and sustainable peace. And as a result, and as several ongoing situations attest, the Council will find itself caught between the hammer and the anvil, damned if it withdraws prematurely and doubly damned if it has no other choice but to extend the peace operation ad-infinitum, and observing rising costs and mounting risks to "We the peoples."

\section{REFERENCES}

Autesserre, Séverine. 2015. Trouble in Peaceland. Argument, in Foreign Policy, October 6.

Call, Charles T. 2012. Building States to Build Peace? A Critical Analysis. Journal of Peacebuilding o Development 4 (2): 60-74.

Center for Strategic and International Studies. 2015. Smart Women, Smart Power: Integrating a "People-Centered" Approach in Foreign Policy. Video, 1:25:24, March 11. https://www.youtube.com/watch?v=myk7FDScMD0. Accessed 9 Nov 2017.

de Coning, Cedric, John Karlsrud, and Paul Troost. 2015. Towards More People-Centric Peace Operations: From 'Extension of State Authority' to 'Strengthening Inclusive State-Society Relations'. Stability: International Journal of Security and Development 4 (1): 1-13.

G7plus. 2017. New Deal Implementation. G7plus.org. http://www.g7plus.org/ en/our-work/new-deal-implementation. Accessed 30 Nov 2017.

Husain, Zahra. 2015. Norman Rockwell's United Nations. UN Foundation Blog, June 30. http://unfoundationblog.org/norman-rockwells-united-nations/. Accessed 9 Nov 2017.

Interpeace. 2016. Strengthening Peace Through 'Resilience' in the 2030 Agenda For Sustainable Development. Policy Brief: Resilience and the SDGs. http:// www.interpeace.org/wp-content/uploads/2016/06/2016-FAR-Brief-2-Resilience-and-the-SDGs.pdf. Accessed 9 Nov 2017.

Karlsrud, John. 2015. How Can the UN Move Towards More People-Centered Peace Operations? Global Peace Operations Review, September 23. http:// peaceoperationsreview.org/thematic-essays/people-centered-reform-atthe-un/. Accessed 30 Nov 2017.

Leiva-Roesch, Jimena, Youssef Mahmoud, and Steve Nation. 2014. Building a Sustainable Future Requires Leadership from State and Citizen. International Peace Institute: Global Observatory. https://theglobalobservatory.org/ 2014/09/sustainable-future-leadership-state-citizen/. Accessed 9 Nov 2017.

Mahmoud, Youssef. 2016. With New Resolutions, Sustaining Peace Sits at Heart of UN Architecture. New York: International Peace Institute, Global Observatory.

Norman Rockwell Museum. 2014. Rockwell's 'Golden Rule'. Norman Rockwell Museum, Blog Post, February 5. http://www.nrm.org/2014/02/golden_ rule/. Accessed 9 Nov 2011. 
Reimers, Fernando. 2015. We the Peoples... and the United Nations 70th General Assembly. The Huffington Post, September 15.

Richmond, P. Oliver, and Roger Mac Ginty. 2014. Where Now for the Critique of the Liberal Peace? Cooperation and Conflict 50 (2): 171-189.

Roberts, David. 2010. From Liberal to Popular Peace? openDemocracy, October 29. https://www.opendemocracy.net/david-roberts/from-liberal-to-popular-peace. Accessed 9 Nov 2017.

Schlesinger, Stephen C. 2004. Act of Creation: The Founding of the United Nations. New York: Basic Books.

United Nations Development Programme. 1990. Human Development Report 1990. http://hdr.undp.org/en/reports/global/hdr1990. Accessed 9 Nov 2017.

United Nations Development Programme. 2017. About Human Development. New York: United Nations Development Programme. http://hdr.undp.org/ en/humandev. Accessed 14 Nov 2017.

United Nations. 2004. Report by Panel of Eminent Persons on United NationsCivil Society Relations. New York: United Nations.

United Nations. 2014. Secretary-General Appoints High-Level Independent Panel on Peace Operations. New York: United Nations.

United Nations. 2015a. Report of the High-Level Independent Panel on Peace Operations on Uniting Our Strengths for Peace: Politics, Partnership and People. New York: United Nations.

United Nations. 2015b. The Future of UN Peace Operations: Implementation of the Recommendations of the High-Level Independent Panel on Peace Operations. New York: United Nations.

United Nations. 2015c. 7564th Security Council Meeting. November 20. http://www.securitycouncilreport.org/atf/cf/\%7B65BFCF9B-6D274E9C-8CD3-CF6E4FF96FF9\%7D/s_pv_7564.pdf. Accessed 9 Nov 2017.

United Nations. 2015d. Statement by the President of the Security Council. November 25. http://www.un.org/en/ga/search/view_doc.asp?symbol=S/ PRST $/ 2015 / 22$. Accessed 9 Nov 2017.

United Nations. 2016a. Report of the Special Committee on Peacekeeping Operations. March 15. New York: United Nations General Assembly.

United Nations. 2016b. Conclusions and Observations by the President of the Seventieth Session of the UN General Assembly. May 19. http://www.un.org/ $\mathrm{pga} / 70 /$ wp-content/uploads/sites/10/2015/08/Thematic-Debate-on-UNPeace-and-Security-Conclusions-Observations-20-May-2016-1.compressed.pdf. Accessed 9 Nov 2017.

United Nations. 2016c. United Nations Security Council Resolution 2282. New York: United Nations.

United Nations. 2016d. United Nations Security Council Resolution 2301. New York: United Nations. 
United Nations. 2016e. United Nations Security Council Resolution 2295. New York: United Nations.

United Nations. 2018. United Nations Security Council Resolution 2423. New York: United Nations.

van Tongeren, Paul. 2005. People Building Peace: Key Messages and Essential Findings. In People Building Peace II: Successful Stories of Civil Society (Project of the European Centre for Conflict Prevention), ed. Paul van Tongeren, Malin Brenk, Marte Hellema, and Juliette Verhoeven. Boulder: Lynne Rienner. 
Open Access This chapter is licensed under the terms of the Creative Commons Attribution 4.0 International License (http://creativecommons.org/licenses/ by $/ 4.0 /$ ), which permits use, sharing, adaptation, distribution and reproduction in any medium or format, as long as you give appropriate credit to the original author(s) and the source, provide a link to the Creative Commons license and indicate if changes were made.

The images or other third party material in this chapter are included in the chapter's Creative Commons license, unless indicated otherwise in a credit line to the material. If material is not included in the chapter's Creative Commons license and your intended use is not permitted by statutory regulation or exceeds the permitted use, you will need to obtain permission directly from the copyright holder.

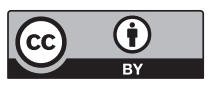

